Acta vet. scand. $1969,10,18-35$.

From the National Veterinary Institute, Stockholm, Sweden.

\title{
STUDIES ON ASPERGILLUS FUMIGATUS; CASEIN PRECIPITATING AND PROTEOLYTIC EFFECTS OF MYCELIAL FILTRATE
}

By

Lars Rutqvist

Schäffer (1900) and Butkewitch (1903) seem to have been the first to focus attention on the proteolytic activity of microfungi. The occurrence and properties of proteolytic enzymes from various fungus species were subsequently studied by several authors. Literature in this field was reviewed by e.g. Ito (1950), Gorbach \& Koch (1955), Koch \& Dedic (1957), Hagihara (1960), Davies (1963) and Roper \& Fennell (1965).

In connection with investigation of the proteolytic activity of several fungus species, a gelatin hydrolyzing effect of Aspergillus fumigatus (AF) was reported to be exerted by living organisms in pure culture (Jensen 1931), extracted mycelial material (Maxwell 1950, Dingle \& Solomons 1952), and by fluid culture medium in which AF was cultured (Dion 1950a, b, Dingle \& Solomons). Ayres \& Tobie (1943) demonstrated moderate casein hydrolyzing activity in extracted mycelial material from 4 AF strains, and Amatayakul (1955) observed low fibrinolytic activity in 1 strain.

Proteolytic activity measured by breakdown of gelatin and casein was demonstrated by Jönsson \& Martin (1964) in culture medium in which AF had been cultured. Three activity optima were observed at $\mathrm{pH}$ values around $3,6.5$ and 10. A subsequent study indicated that the activity in neutral and alkaline environment was caused by the same enzyme (Martin \& Jönsson 1965).

By means of electrophoretic separation combined with reactions for enzyme characterization, Tran Van $\mathrm{Ky}$ et al. (1966) demonstrated proteolytic activity in mycelial extracts of 21-day AF cultures. A casein precipitating enzyme (CP enzyme) was 
demonstrated by Sandvik (1967) in the fluid phase of frozen and thawed skimmilk agar cultures from e.g. AF.

In addition to haemolysin and toxin (Rutqvist 1965, 1968, Rutqvist \& Persson 1966), mycelial filtrates of AF have proved to contain a proteolytic enzyme. An account is given in the following of a study of this enzyme with respect to (1) casein precipitating ability, (2) casein and gelatin hydrolyzing effect, and (3) relation to toxin and haemolysin.

\section{MATERIAL AND METHODS}

Strains. The AF strains used derived from a collection previously described (Rutquist 1965).

Media. The strains were maintained at room temperature on agar slants of Sabouraud's agar, and were recultured once a month. Cultures for production of mycelial filtrates were made in fluid medium, consisting of proteose-peptone Difco $(1.5 \%)$, yeast extract Difco $(0.5 \%)$, dextrose $(3 \%)$ and $\mathrm{NaCl}(0.5 \%)$ in distilled water, $\mathrm{pH}$ 7.2.

Filtrate preparation. Strain cultures grown for 7 days at $20^{\circ} \mathrm{C}$ on Sabouraud's agar in agar slants were suspended with $10 \mathrm{ml}$ of proteose-peptone broth per tube, and $1 \mathrm{ml}$ was transferred to $300 \mathrm{ml}$ of fluid medium in Roux flasks. The mycelial mats, which after 3 days' incubation at $37^{\circ} \mathrm{C}$ had grown on the surface of the medium, were washed on harvesting with sterile, distilled water, dried between filter paper and kept at $-20^{\circ} \mathrm{C}$ for $2-4$ days.

To $100 \mathrm{~g}$ of frozen mycelial material was added $75 \mathrm{ml}$ of sterile distilled water, and the mixture was homogenized in a mixer at 11,000 r.p.m. The homogenate was stored at $4^{\circ} \mathrm{C}$ for 5 days and centrifuged at $2,500 \times \mathrm{g}$ for 20 min., after which the supernatant was filtered through a Seitz EK filter. The filtrate was frozen, and stored at $-20^{\circ} \mathrm{C}$.

The ethanol and acetone precipitates were obtained by addition of cold ethanol and acetone, respectively, to the crude filtrate with a $\mathrm{pH}$ of 7.0. When the mixture had been kept for $17 \mathrm{hrs}$. at $4^{\circ} \mathrm{C}$, the precipitate formed was separated by centrifugation $(2,500 \times \mathrm{g}$ for 20 min.), and dried in an exsiccator for $24 \mathrm{hrs}$. In ammonium sulphate precipitation, the ammonium sulphate was added in substance to the crude filtrate ( $\mathrm{pH}$ 7.0). The precipitate formed after $17 \mathrm{hrs}$.' storage at $4^{\circ} \mathrm{C}$ was separated off by centrifugation. The precipitate was dissolved in a small amount of sterile distilled water, dialyzed and freezedried. All dried preparations were kept at $4^{\circ} \mathrm{C}$, and on dissolving in distilled water, butanol to $1 \%(\mathrm{v} / \mathrm{v})$ was added as preservative. Butanol $(1 \%)$ was also added to thawed crude filtrates and dialysates of crude filtrates intended for activity determinations, immediately after thawing and dialysis, respectively. It is evident from Fig. 7 that butanol had no inhibitory effect on the activities determined.

Toxic activity. The toxic activity of the various filtrate preparations was determined as the $\mathrm{LD}_{50}$ titre in mice (denoted here as 
MLD $_{50}$ ) by Kärber's formula. Groups of 10 mice belonging to the NMRI strain (Naval Medical Research Institute, Bethesda, Md., USA), weighing 16-18 g, were inoculated intraperitoneally with each of a series of 10-fold dilutions of the filtrate. The dilution fluid was $0.9 \%$ $\mathrm{NaCl}$ solution. The volume of the inoculum was $0.5 \mathrm{ml}$ per mouse. The mice were kept under observation for 10 days.

Haemolytic activity. Sheep erythrocytes in Alsever's fluid, kept at $4^{\circ} \mathrm{C}$ for maximally 4 days, were washed with $1 / 10 \mathrm{M}$ veronal buffer, $\mathrm{pH} 7$, and diluted in the buffer to a $2 \%$ suspension. Of this suspension, $0.5 \mathrm{ml}$ was added to $0.5 \mathrm{ml}$ of the strain filtrate in 2-fold serial dilutions with $0.9 \% \mathrm{NaCl}$. The haemolytic activity was read after incubation for $30 \mathrm{~min}$. at $37^{\circ} \mathrm{C}$ and $90 \mathrm{~min}$. at $20^{\circ} \mathrm{C}$. The smallest quantity of filtrate producing complete haemolysis was taken as the titre of haemolytic activity, and expressed as 1 haemolytic unit (HU). As in the toxicity determinations, the quantity of dry substance in the various filtrate preparations investigated was $5-50 \mathrm{mg} / \mathrm{ml}$.

Casein precipitating activity. With certain modifications, the casein precipitating activity (CP activity) of the filtrate preparations in fluid and solid casein substrates was determined according to Sandvik (1962).

The casein stock solution was prepared by dissolving $4 \mathrm{~g}$ of sodium caseinate (Hammarsten grade, Hopkins \& Williams Ltd., Chadwell Heath, England) to $100 \mathrm{ml}$ with distilled water, the $\mathrm{pH}$ being adjusted to 7.5 with $2 \mathrm{~N}-\mathrm{NaOH}$.

To determine the precipitation in casein solution, the stock solution was diluted with distilled water to a casein concentration of $0.2 \%$, and merthiolate to $0.01 \%(\mathrm{w} / \mathrm{v})$ was added. A solution not used immediately was kept at $-20^{\circ} \mathrm{C}$. Before each determination, the $\mathrm{pH}$ of the solution was adjusted to the desired value with $0.1 \mathrm{~N}-\mathrm{NaOH}$ or $0.1 \mathrm{~N}-\mathrm{HCl}$, and $5-\mathrm{ml}$ volumes were transferred to test tubes. After $15 \mathrm{~min}$. equilibration in a thermostat at $37^{\circ} \mathrm{C}, 0.2 \mathrm{ml}$ of mycelial filtrate dilution was added, after which the samples were incubated in a thermostat at $37^{\circ} \mathrm{C}$ for $2 \mathrm{hrs}$. The turbidity arising in the sample was recorded in a Beckman Model B spectrophotometer at $600 \mathrm{~m} \mu$, after correction against a blank, and given as the percentage change in turbidity in relation to the blank. This differed from the sample only in that the filtrate solution added had been inactivated by boiling for $15 \mathrm{~min}$. By diluting the mycelial filtrate with distilled water, the strength of the CP enzyme was adjusted to 60-140 diffusion units (see the following) per $\mathrm{ml}$ reaction mixture in the sample.

In the cases in which the influence of various salts on the casein precipitation was studied, 4-ml volumes of casein substrate and $1 \mathrm{ml}$ of distilled water were used, the content of the various salts being adjusted to the desired concentration.

Quantitative determination of the CP enzyme in filtrate preparations was performed in casein agar, the casein being taken from the aforementioned casein stock solution. The final concentrations of the substances contained in the casein agar were: $0.25 \%$ casein, $1.05 \%$ Bacto agar Difco, $0.004 \mathrm{M}-\mathrm{MgCl}_{2}$ added as $8 \%(\mathrm{w} / \mathrm{v})$ solution, 
and $0.01 \%(\mathrm{w} / \mathrm{v})$ merthiolate. After mixing, the $\mathrm{pH}$ was adjusted to 6.2 , and the substrate was poured in $2 \mathrm{~mm}$ thick layers into Petri dishes $185 \mathrm{~mm}$ in diameter. After the agar had set, holes $6 \mathrm{~mm}$ in diameter were punched in it. These were filled with $0.025 \mathrm{ml}$ of filtrate, diluted 2-fold with distilled water, and the agar plates were incubated in a moist chamber at $37^{\circ} \mathrm{C}$ - unless otherwise stated -for $19 \mathrm{hrs}$. The diameter of the precipitation zones appearing around the holes was measured by means of a loupe $(2.5 \times$ magnification $)$ and millimetre paper.

Sandvik's (1962) definition of the diffusion unit (DU) and titre of the CP enzyme (CP titre) were used. Thus, the CP titre was calculated by plotting the diameters of the precipitation zones of the 4-5 greatest filtrate dilutions on the ordinate as a function of the degree of dilution, after which the resulting curve was extrapolated to the abscissa. The point of intersection of the curve and the abscissa gives the filtrate dilution of which $0.025 \mathrm{ml}$ contains $1 \mathrm{DU}$.

A logarithmic standard curve was obtained by plotting on the ordinate the diameters of the precipitation zones against the logarithms of the number of DU in $0.025 \mathrm{ml}$ of the filtrate dilutions used. Such a standard curve was used only for calculating the residual activity of the CP enzyme after heat inactivation.

All quantitative determinations of the CP enzyme in mycelial filtrates were based on the mean of $2-3$ parallel measurements per filtrate.

Casein hydrolyzing activity. Spectrophotometric determination of the casein hydrolyzing activity of the mycelial filtrate was performed by the method of Kunitz (1947), as described by Narayanan \& Shanmugasundaram (1966). The desired quantity of nitrogen per ml was obtained by diluting the dialyzed mycelial filtrate with distilled water. One $\mathrm{ml}$ of filtrate dilution was added to $4 \mathrm{ml}$ of $0.15 \mathrm{M}$ acetate buffer, $\mathrm{pH} 5.8$, and $1 \mathrm{ml}$ of $1 \%(\mathrm{w} / \mathrm{v})$ casein (Hammarsten grade) in 0.01 $\mathrm{N}-\mathrm{NaOH}$ solution, so that the reaction mixture had a $\mathrm{pH}$ of 6.2 . The sample was incubated in a water bath at $45^{\circ} \mathrm{C}$ for 60 min., after which the reaction was interrupted by addition of $1 \mathrm{ml}$ of $0.6 \mathrm{M}$ trichloroacetic acid (TCA). After $30 \mathrm{~min}$. the precipitate formed was filtered off. Blanks, in which TCA was added to the filtrate-buffer solution before the casein solution, which was also incubated for $60 \mathrm{~min}$. at $45^{\circ} \mathrm{C}$, were prepared parallel with each sample. To $2 \mathrm{ml}$ of TCA filtrate were added $4 \mathrm{ml}$ of $0.5 \mathrm{~N}-\mathrm{NaOH}$ solution and $1 \mathrm{ml}$ of Folin-Ciocalteu phenol reagent (Merck), diluted 1:3 with distilled water. After exactly $20 \mathrm{~min}$. the intensity of blue colour formed by the breakdown products of casein in the sample was read against the relevant blank in a Beckman Model B spectrophotometer at $640 \mathrm{~m} \mu$. The increased optical density in the sample in relation to the blank was taken as a measure of the casein hydrolyzing ability of the enzyme, and was denoted as the caseinase activity.

Gelatin hydrolyzing activity. The ability of the mycelial filtrate to release amino nitrogen by gelatin hydrolysis was determined at different $\mathrm{pH}$ values by means of Sörensen's (1908) formol titration, 
modified according to Bworschack et al. (1952). To $10 \mathrm{ml}$ of $10 \%$ $(\mathrm{w} / \mathrm{v})$ gelatin solution (Gelatina, Ph. Nord. AKL 653599 P 50, Apotekarnas Droghandel AB, Sweden) with $1 \%$ butanol (v/v) were added $2.5 \mathrm{ml}$ of crude filtrate and $2.5 \mathrm{ml}$ of sterile distilled water. The $\mathrm{pH}$ was adjusted to the desired value with $2 \mathrm{~N}-\mathrm{HCl}$ or $2 \mathrm{~N}-\mathrm{NaOH}$, after which the sample was incubated, in a closed vessel, in a water bath at $37^{\circ} \mathrm{C}$ for $4 \mathrm{hrs}$. Samples with a pH $<8.5$ were adjusted after incubation to 8.5 with $2 \mathrm{~N}-\mathrm{NaOH}$, whereas samples with a $\mathrm{pH}>8.5$ were left at their original $\mathrm{pH}$ level. Five $\mathrm{ml}$ of neutralized formalin (38\% formaldehyde) were added to each sample, which was then titrated back to $\mathrm{pH} 8.5$ or to its original $\mathrm{pH}$ with $0.07 \mathrm{~N}-\mathrm{NaOH}$. One ml of titration fluid was considered to represent $1 \mathrm{mg}$ of released amino nitrogen (Dworschack et al.). The difference between the quantity of titration fluid in the sample and that in a blank corresponding to each sample, in which the filtrate was inactivated by boiling for $15 \mathrm{~min}$. gives the amount of amino nitrogen released by $2.5 \mathrm{ml}$ of filtrate. The gelatin hydrolyzing ability was denoted as the gelatinase activity.

Nitrogen content. The nitrogen content of different filtrate preparations was determined by Kjeldahl's micro method in solutions with 5-50 $\mathrm{mg}$ of dry substance per $\mathrm{ml}$, and related to the dry substance.

pH determination. All $\mathrm{pH}$ determinations were made with a glass electrode, using a type $28 \mathrm{pH}$ meter (Radiometer, Copenhagen, Denmark).

Weight determination. The weight of the dry substance in the different filtrate preparations was determined by using a type $\mathrm{H} 6$ analytical scales (E. Mettler, Zürich, Switzerland).

Dialysis. All diallyses were performed against running tap water for $17 \mathrm{hrs}$., followed by distilled water for $2 \mathrm{hrs}$.

Presentation of results. Each experiment was made with filtrate preparations from 2 to $14 \mathrm{AF}$ strains, the results obtained being essentially similar. Consequently, representative experiments are presented in the following.

\section{EXPERIMENTAL AND RESULTS}

\section{Casein precipitation}

Influence of $p H$. It is evident from Fig. 1 that the CP enzyme in crude filtrates and dialyzed filtrates gave maximal turbidity in casein solutions at $\mathrm{pH} \mathrm{6.2--6.4.}$

Influence of salts. Low concentrations of phosphate or acetate buffer $(0.0025 \mathrm{M})$, as well as of $\mathrm{NaCl}(0.0005 \mathrm{M})$, in the casein solution showed a distinct tendency to raise the casein precipitating ability of the CP enzyme in the mycelial filtrate. Rising concentrations of both buffers, as well as of $\mathrm{NaCl}$, produced a marked decrease in the enzymatic turbidity increase, as seen in Figs. 2 and 3. 

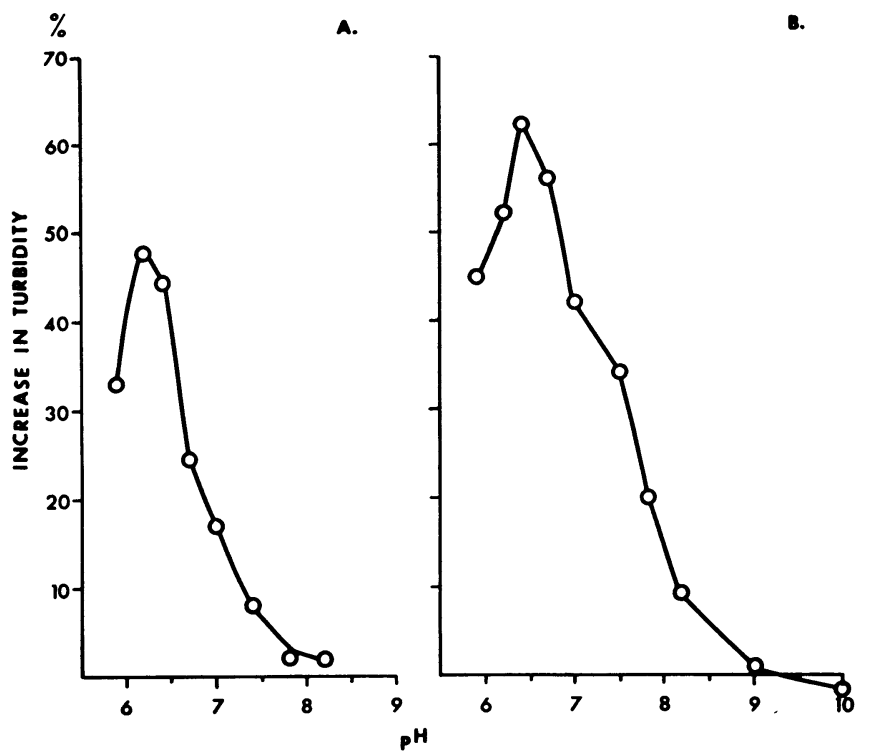

$\mathrm{Fig} \mathrm{u} \mathrm{r} \mathrm{e} \mathrm{1.} \mathrm{Influence} \mathrm{of} \mathrm{pH}$ on turbidity of casein solution caused by CP enzyme in A) crude filtrate, B) dialyzed filtrate. Incubation $2 \mathrm{hrs}$. at $37^{\circ} \mathrm{C}$. Aspergillus fumigatus strain 938 .

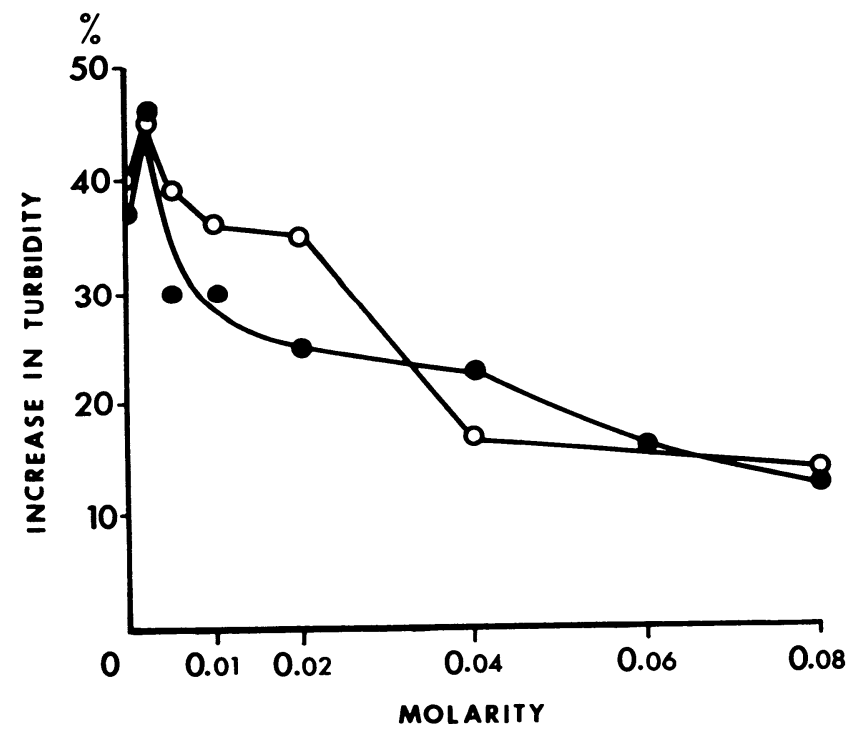

Fig u re 2. Influence of acetate and phosphate buffers on turbidity of casein solution at $\mathrm{pH} 6.2$ caused by $\mathrm{CP}$ enzyme in crude filtrate. Incubation $2 \mathrm{hrs}$. at $37^{\circ} \mathrm{C}$. Aspergillus fumigatus strain 6869 .

o- o phosphate buffer

- acetate buffer 


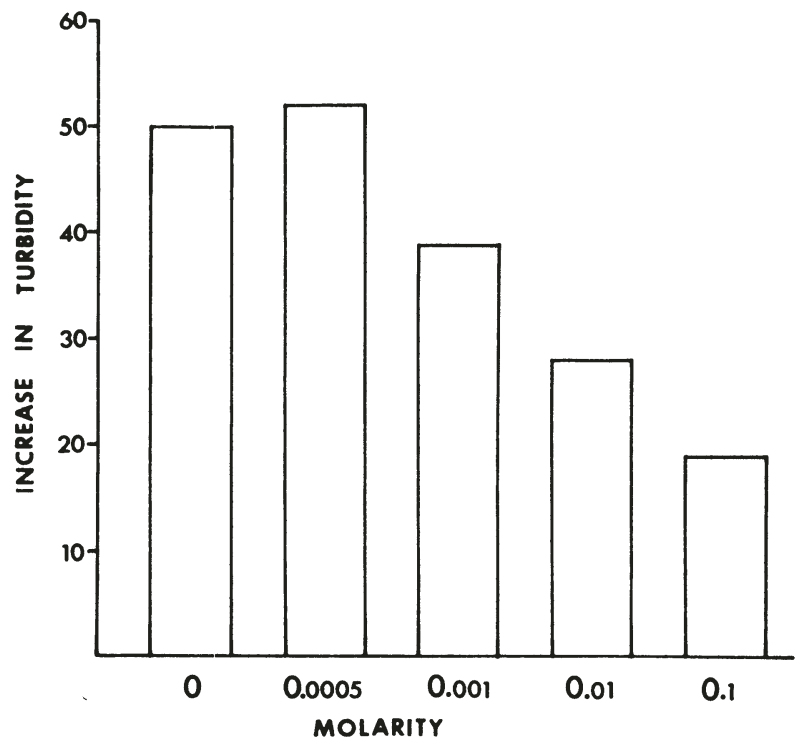

Figure 3. Influence of $\mathrm{NaCl}$ on turbidity of casein solution at $\mathrm{pH} 6.2$ caused by $\mathrm{CP}$ enzyme in crude filtrate. Incubation $2 \mathrm{hrs}$. at $37^{\circ} \mathrm{C}$. Aspergillus fumigatus strain 6869 .

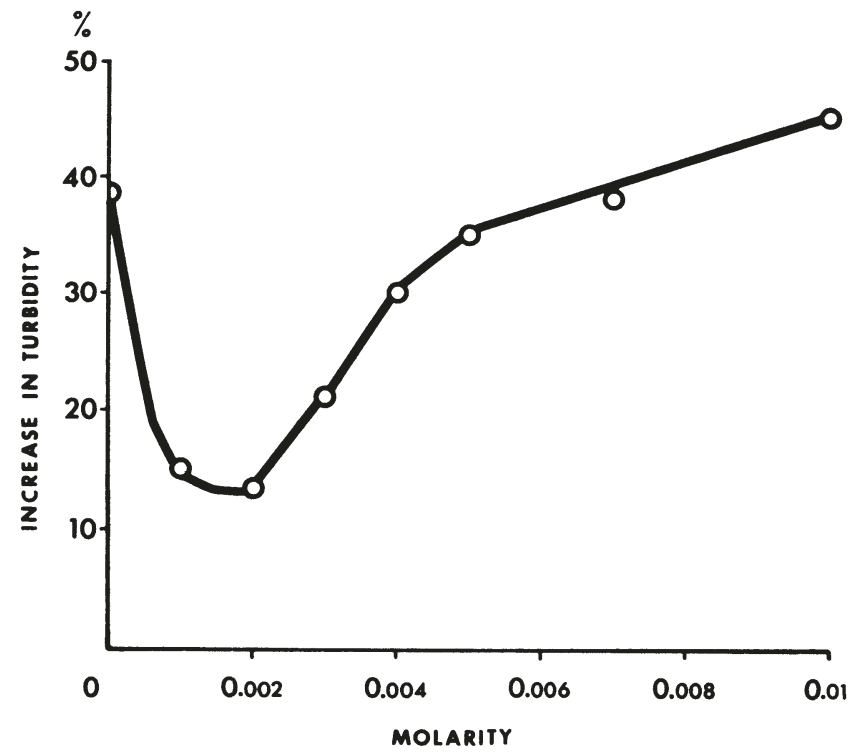

F i g u re 4. Influence of $\mathrm{MgCl}_{2}$ on turbidity of casein solution at pH 6.2 caused by CP enzyme in crude filtrate. Incubation $2 \mathrm{hrs}$. at $37^{\circ} \mathrm{C}$. Aspergillus fumigatus strain 6869 . 
As can be inferred from Fig. 4, the turbidity produced by the CP enzyme in the mycelial filtrate decreased in casein solutions containing $0.001-0.002 \mathrm{M}-\mathrm{MgCl}_{2}$, after which rising concentration was associated with increasing turbidity. It could be noted that a $0.004 \mathrm{M}$ concentration of $\mathrm{MgCl}_{2}$ in the casein agar produced more distinct precipitation zones caused by the enzyme, concurrently with the lytic effect of the CP enzyme on the inner edge of the precipitation zones becoming more conspicuous. Concentrations of $\mathrm{MgCl}_{2}$ exceeding $0.004 \mathrm{M}$ in the casein agar resulted in increasing opacity of the agar, which made it more difficult to read the precipitation zones.

Influence of incubation temperature. The influence of the incubation temperature on the size of the precipitation zones in casein agar produced by the CP enzyme in mycelial filtrate is evident from Fig. 5. The largest precipitation zones were obtained on incubation at $45^{\circ} \mathrm{C}$, whereas incubation at $50^{\circ} \mathrm{C}$ resulted in

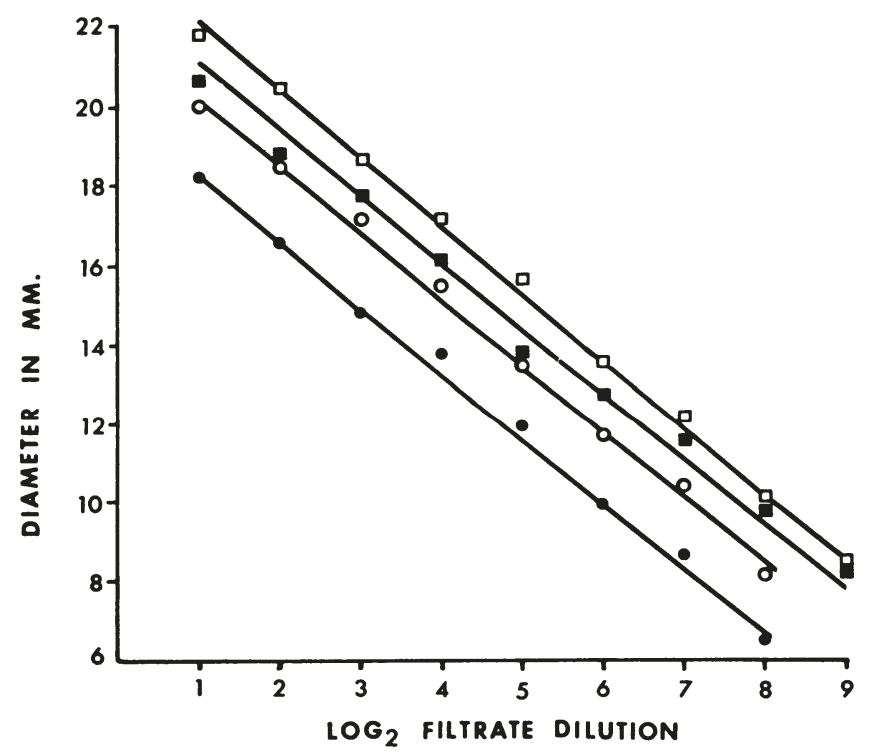

$\mathrm{Fig}$ u r e 5. Diameter of precipitation zones in casein agar at $\mathrm{pH} 6.2$ caused by CP enzyme in crude filtrate at different incubating temperatures. Incubation time $19 \mathrm{hrs}$. Aspergillus fumigatus strain 6869 .

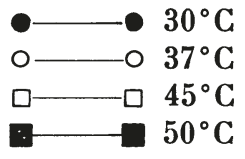


smaller zones, which were nevertheless larger than after incubation at $37^{\circ} \mathrm{C}$.

Influence of heat. Crude filtrates with a $\mathrm{pH}$ of 6.7 were heated in 0.5-ml volumes in thin-walled, stoppered glass tubes for 15 min. in a water bath at various temperatures. After heating, the tubes were cooled under running water, and kept at $4^{\circ} \mathrm{C}$ until the activity was determined, which took place within $2 \mathrm{hrs}$. of heating. The residual activity of the CP enzyme in the heated filtrate was determined by comparing the diameter of the precipitation zones in casein agar with a logarithmic standard curve, plotted for unheated filtrate preparations. The inactivation curve is seen in Fig. 6. Complete inactivation of the CP enzyme in crude filtrate was obtained after heating at $80^{\circ} \mathrm{C}$.

When crude filtrate, $\mathrm{pH} \mathrm{7,} \mathrm{was} \mathrm{incubated} \mathrm{in} \mathrm{a} \mathrm{thermostat} \mathrm{at}$ $37^{\circ} \mathrm{C}$ for 14 days, it was observed that the CP enzyme had the greatest stability, and the haemolysin the lowest (Fig. 7 A). After the initial reduction of activity, the CP enzyme showed a tendency, after incubation for $3-5$ days, to be reactivated or, at any rate, stabilized.

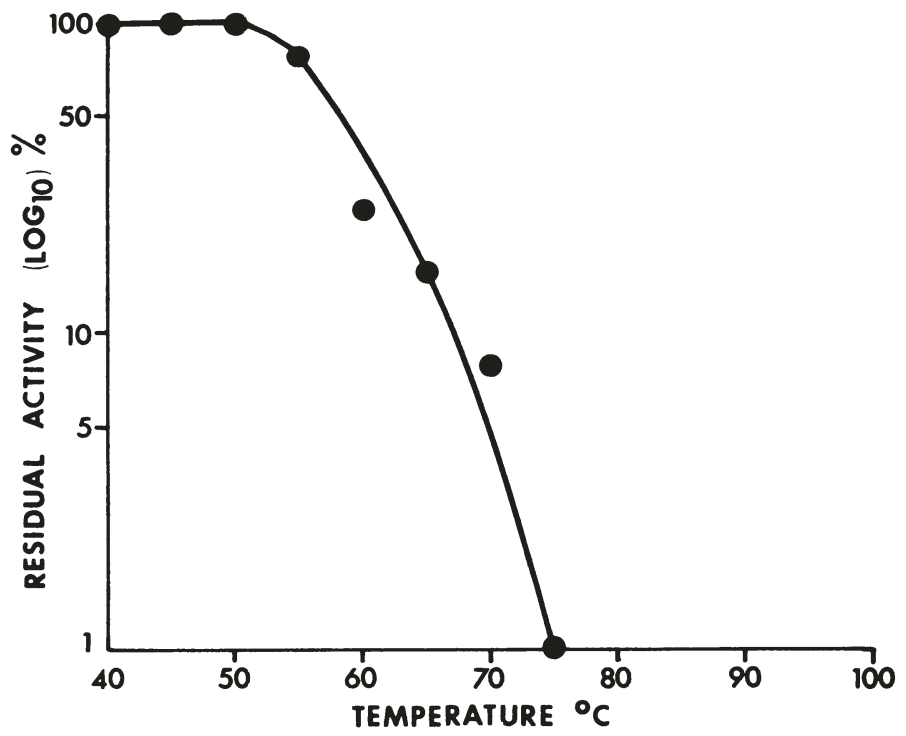

$\mathrm{F}$ i g u r e 6. Inactivation at $\mathrm{pH} 6.7$ of $\mathrm{CP}$ enzyme in crude filtrate at different temperatures. Aspergillus fumigatus strain 6869 . 
As is apparent from Fig. $7 \mathrm{~A}$ and $\mathrm{B}$, no definite effect of butanol on the stability of the haemolytic, toxic or casein precipitating activity could be observed.

\section{Casein and gelatin hydrolysis}

To determine whether casein precipitating filtrate also hydrolyzed protein substrate, the caseinase activity was investigated in 14 strain filtrates and the gelatinase activity in 2. In every case, caseinase and gelatinase activity, respectively, was demonstrated. As seen in Fig. 8, the caseinase activity in dialyzed filtrate, $\mathrm{pH}$ 6.2, increased with rising nitrogen concentration in the filtrate.

The optimal gelatinase activity in crude filtrate was obtained when the filtrate affected the gelatin at $\mathrm{pH} 6-8$ (Fig. 9).

\section{Relation to haemolysin and toxin}

On fractionation of mycelial filtrate with acetone, ethanol or ammonium sulphate, it was found that the highest CP activity per $\mathrm{mg}$ nitrogen was obtained in the ethanol precipitate when 1 part filtrate was precipitated with 3 parts ethanol (Table 1). No haemolytic and only inappreciable toxic activity could be demon-

A.

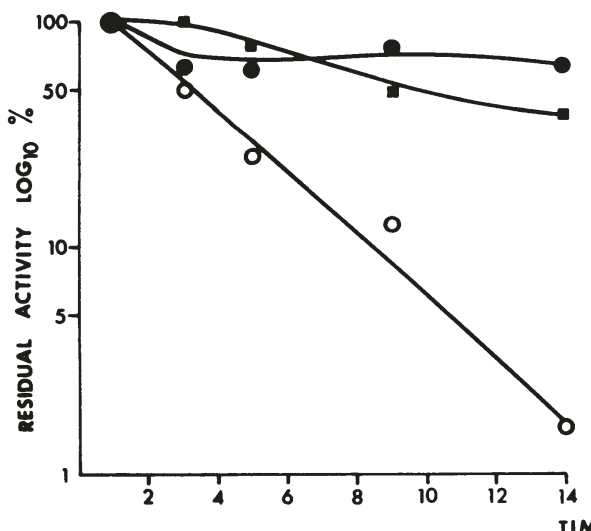

B.

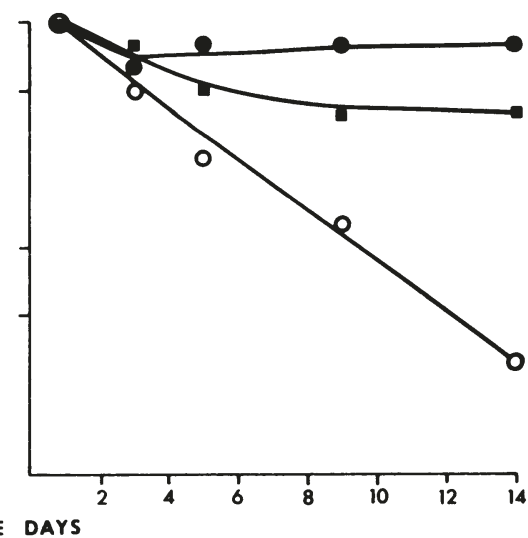

F i g u r e 7. Inactivation at $37^{\circ} \mathrm{C}$ and $\mathrm{pH} 7.0$ of toxin $\left(\mathrm{MLD}_{50}\right)$, haemolysin (HU) and CP enzyme (DU) in crude filtrate. A) without and

B) with $1 \%$ butanol. Aspergillus fumigatus strain 938.

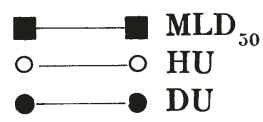




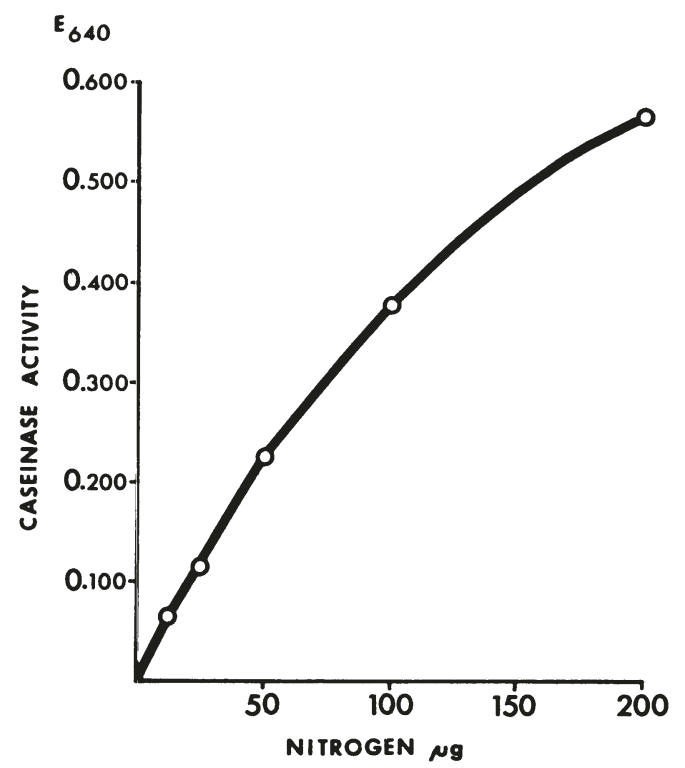

F i g u r e 8. Casein hydrolyzing effect at $\mathrm{pH} 6.2$ of dialyzed filtrate in relation to nitrogen content of the filtrate. Digestion: $1 \mathrm{hr}$. at $45^{\circ} \mathrm{C}$. Aspergillus fumigatus strain 6869 .

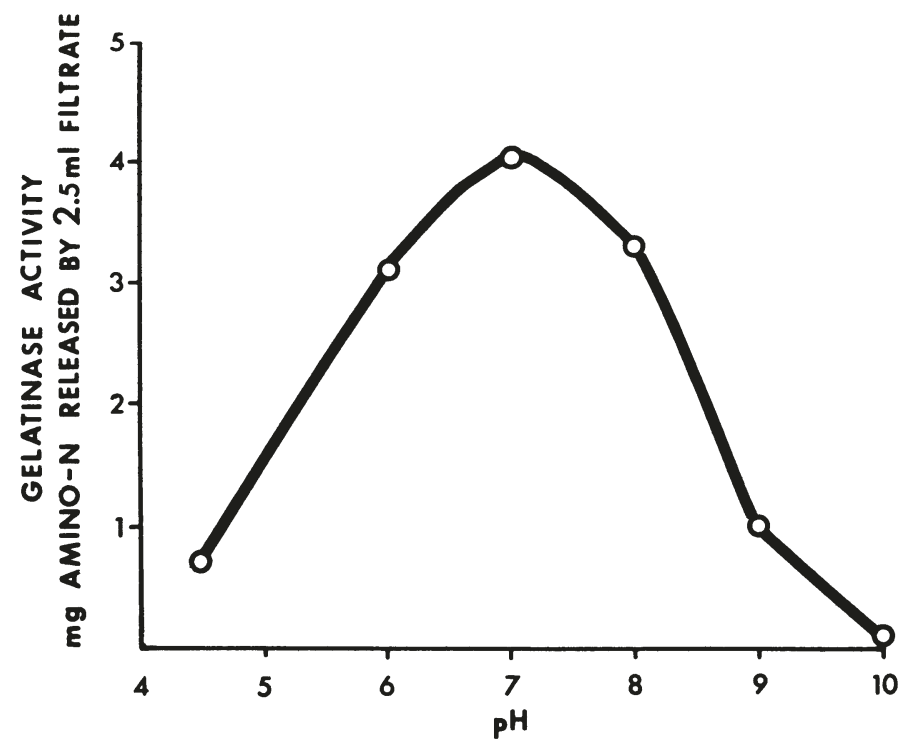

Figur e 9. Gelatin hydrolyzing effect of crude filtrate at different $\mathrm{pH}$ values. Digestion: $4 \mathrm{hrs}$. at $37^{\circ} \mathrm{C}$. Aspergillus fumigatus strain 6869 . 


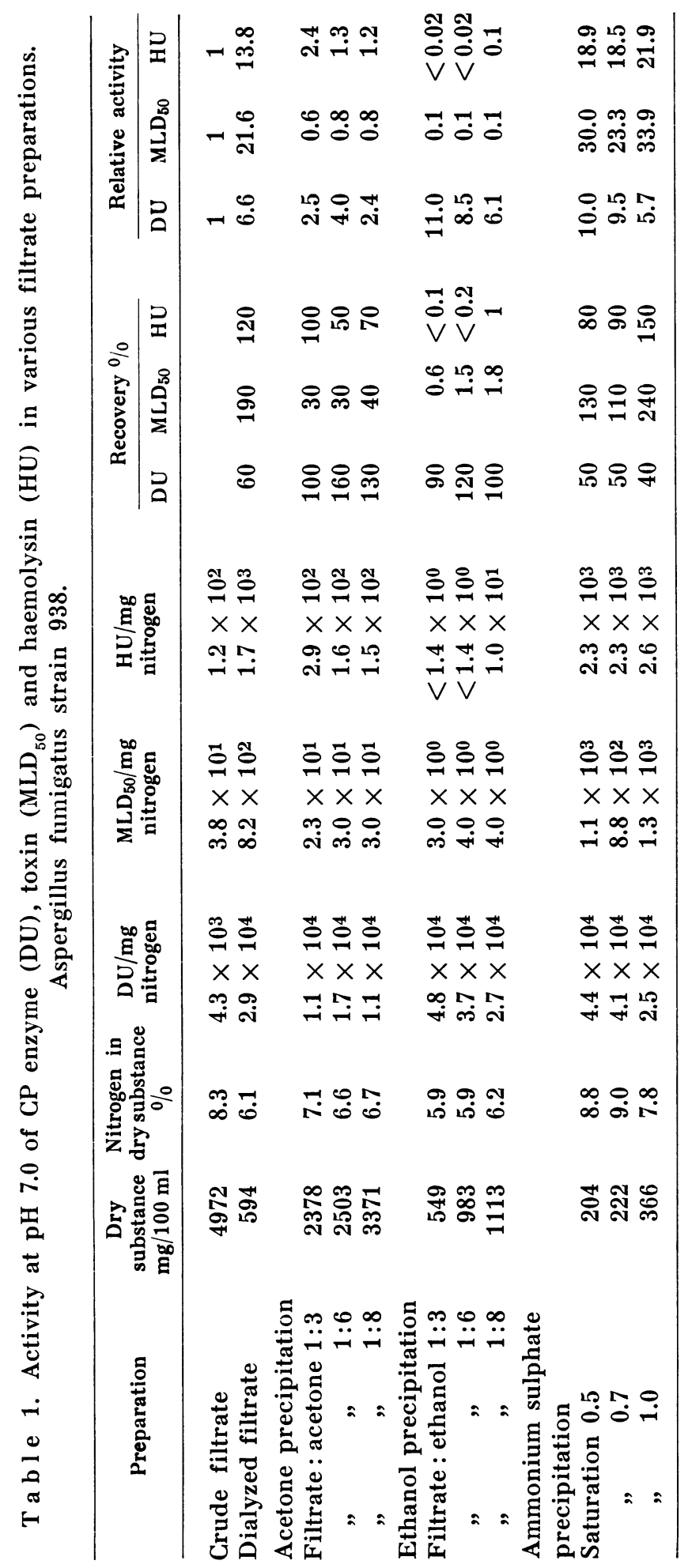


strated in this fraction. When the filtrate was precipitated with increasing amounts of ethanol, the CP activity per mg nitrogen fell.

On precipitation of 1 part filtrate with 8 parts ethanol, small amounts of haemolysin appeared in the precipitate. No marked difference could be demonstrated between the toxic activity of precipitates obtained by precipitating filtrate with varying amounts of ethanol.

The highest toxic and haemolytic activities per mg nitrogen were measured in the ammonium sulphate-precipitated filtrate fractions. The CP activity in these fractions coincided closely with that of the ethanol fractions. Saturation of filtrate with ammonium sulphate to $50 \%$ or $100 \%$ produced no definite difference in the toxic or haemolytic activity of the precipitate per $\mathrm{mg}$ nitrogen. The CP activity per $\mathrm{mg}$ nitrogen was, on the other hand, lower in the latter filtrate than in the former.

In relation to crude filtrate, the $\mathrm{CP}$ and haemolytic activities per $\mathrm{mg}$ nitrogen were somewhat increased in precipitates from acetone-treated filtrates, whereas the toxic activity tended to be lower. As can be inferred from Table 1, dialysis alone resulted in considerable purification of toxin, haemolysin and CP enzyme.

\section{DISCUSSION}

The principles of the casein precipitating reaction (CP reaction) induced by bacterial proteolytic enzymes were thoroughly investigated and discussed by Sandvik (1962). On the basis of this reaction, he also devised a method for quantitative determination of the CP enzyme.

To study the relations between $\mathrm{CP}$ enzyme, haemolysin and toxin in various preparations of $\mathrm{AF}$ mycelial filtrates, the $\mathrm{CP}$ reaction was used, in the present work, in the first place for quantitative determination of the CP enzyme. The influence of salts used in producing the filtrate preparations, or in performing the CP reaction, was also studied. This is because it could not be assumed unconditionally that these salts did, in fact, influence the $\mathrm{CP}$ reaction induced by $\mathrm{CP}$ enzyme from $\mathrm{AF}$ in the same way as the CP reaction caused by bacterial CP enzymes. Moreover, when studying the CP enzyme from AF, the quality of the casein was not the same as that in Sandvik's (1962) investigations of bacterial $\mathrm{CP}$ enzymes. 
In the presence of the salts investigated, the CP reaction caused by CP enzyme from AF proved to be influenced in essentially the same way as that produced by most bacterial CP enzymes. Thus, the reaction was stimulated by low concentrations of acetate buffer, phosphate buffer or sodium chloride, whereas rising concentrations resulted in its successive inhibition. The CP reaction was, on the contrary, inhibited by low concentrations of $\mathrm{MgCl}_{2}$, and stimulated by high ones. Although the $\mathrm{CP}$ enzyme from $A F$ gave a positive $C P$ reaction in casein agar without the presence of $\mathrm{MgCl}_{2}$, the reaction was more distinct, and the lytic effect acting on the inner edge of the precipitation zone was more conspicuous, when $\mathrm{MgCl}_{2}$ was present. A concentration of $\mathrm{MgCl}_{2}$ higher than $0.004 \mathrm{M}$ did, however, produce increasing opacity of the agar, with a resulting difficulty in reading. In accordance with these results, the mycelial material was extracted with distilled water, instead of with physiological saline as earlier (Rutqvist 1965, Rutqvist \& Pehrsson 1966). Precipitated or freeze-dried filtrate preparations were dissolved in distilled water instead of in buffer solution, and $0.004 \mathrm{M}-\mathrm{MgCl}_{2}$ was used in the casein agar in quantitative determination of the CP enzyme.

The optimal incubation temperature for the CP reaction induced by CP enzyme from AF after 19 hrs.' incubation proved to be $45^{\circ} \mathrm{C}$. However, since it was observed that the precipitation zones became diffuse at temperatures above $37^{\circ} \mathrm{C}$, incubation at $37^{\circ} \mathrm{C}$ was preferred.

CP enzyme in crude filtrate was inactivated after heating for 15 min. at $80^{\circ} \mathrm{C}$. After heating at higher temperatures, no reactivation of inactivated enzyme could be observed. On the other hand, on incubation at $37^{\circ} \mathrm{C}$, it was observed that - after an initial reduction in activity - the $\mathrm{CP}$ enzyme showed a tendency, after 3-5 days' incubation, to be reactivated, or at any rate for the activity to be stabilized.

In the environment constituted by a crude filtrate, the causes of such a phenomenon may be complex. So-called active fragments arising by autolysis or inactivation of inhibitor substances with greater heat sensitivity than the enzyme can, for instance, either separately or together be conceivable explanations.

The ability to precipitate casein and to hydrolyze gelatin coincided in all the bacterial CP enzymes studied by Sandvik (1962). The author presumed that, in the individual case, gelatin 
hydrolysis and CP reaction could be ascribed to an identical enzyme. In the present investigation as well, it was found that AF mycelial filtrates with a positive $\mathrm{CP}$ reaction also hydrolyzed casein at a $\mathrm{pH}$ optimal for the $\mathrm{CP}$ reaction, i.e., 6.2. I did not investigate whether this $\mathrm{pH}$ value is also an optimal $\mathrm{pH}$ for casein hydrolysis. The optimal $\mathrm{pH}$ for gelatin hydrolysis seems to lie around $\mathrm{pH} 7$.

In relation to crude filtrate, the CP activity per $\mathrm{mg}$ nitrogen increased in precipitates from ethanol-treated filtrates, concurrently with disappearance of the haemolytic activity and a marked decrease in the toxic activity (Table 1). This shows that the CP enzyme constitutes a principle independent of haemolysin and toxin. The completely different inactivation curves for $\mathrm{CP}$ enzyme, haemolysin and toxin, arising when crude filtrate was stored for any lengthy time at $37^{\circ} \mathrm{C}$, also indicate that the $\mathrm{CP}$ enzyme differs essentially from both toxin and haemolysin.

I did not investigate whether the inappreciable presence or absence of toxin and haemolysin in precipitates from ethanoltreated filtrates is due to these activities not being precipitated by ethanol, or whether they are inactivated on ethanol treatment. The presence of haemolysin in the precipitate when the filtrate was treated with large amounts of ethanol (1 part filtrate to 8 parts ethanol) seems to indicate that inactivation does not occur. In any event, it seems possible to use ethanol precipitation to distinguish, to a great extent, the CP enzyme in AF mycelial filtrates from haemolysin and toxin.

\section{REFERENCES}

Amatayakul, T.: The synthesis of fibrinolysin by fungi. Ohio J. Sci. $1955,55,343-353$.

Ayres, B. \& W. Tobie: The isolation of crude proteolytic enzyme from microorganisms. J. Bact. 1943, 45, 18.

Butkewitch, W.: Umwandlung der Eiweisstoffe durch die niederen Pilze. (Changes of proteins by moulds). Jb. Wiss. Bot. 1903, 38, 147-240. cit. Jensen, H. L.: Soil Sci. 1931, 31, 123-158.

Davies, R.: Microbial extracellular enzymes, their uses and some factors affecting their formation. In Biochemistry of Industrial Microorganisms. Eds. C. Rainbow \& A. H. Rose. Academic Press, London and New York, 1963, 68-150.

Dingle, J. \& G. L. Solomons: Enzymes from micro-fungi. J. appl. Chem. 1952, 2, 395-399. 
Dion, W. M.: The proteolytic enzymes of microorganisms. I. Survey of fungi and actinomycetes for protease production in submerged culture. Canad. J. Res., C 1950a, 28, 577-585.

Dion, W. M.: The proteolytic enzymes of microorganisms. II. Factors affecting the production of proteases in submerged cultures. Canad. J. Res., C 1950b, 28, 586-599.

Dworschack, R. G., H. J. Koepsell \& A. A. Lagoda: Proteolytic enzymes of microorganisms. Evaluation of proteinases produced by molds of the Aspergillus flavus-oryzae group in submerged culture. Arch. Biochem. 1952, 41, 48-60.

Gorbach, G. \& O. G. Koch: Über die proteolytische Aktivität von Aspergillus niger und ihre Beeinflussung durch Spurenelemente. (Studies on the proteolytic activity of Aspergillus niger and the influence of trace elements). Arch. Mikrobiol. 1955, 23, $265-283$.

Hagihara, B.: Bacterial and mold proteases. In The Enzymes, Vol. IV. Eds. P. D. Boyer, H. Lardy and K. Myrbäck. Academic Press, New York and London, 1960, 193-213.

Ito, Y.: On the protease action of Penicillium notatum. I. J. Biochem. (Tokyo) 1950, 37, 51-63.

Jensen, H. L.: The fungus flora of the soil. Soil Sci. 1931, 31, 123-158.

Jönsson, A. G. \& S. M. Martin: Protease production by Aspergillus fumigatus. Agric. Biol. Chem. (Tokyo) 1964, 28, 734-739.

Koch, O. G. \& G. A. Dedic: Beitrag zur proteolytischen Aktivität von Schimmelpilzen. (Contribution to proteolytic activity of moulds). Biochem. Z. 1957, 328, 536-548.

Kunitz, M.: Crystalline soybean trypsin inhibitor. II. General properties. J. gen. Physiol. 1947, 30, 291-310.

Martin, S. M. \& A. G. Jönsson: An extracellular protease from Aspergillus fumigatus. Canad. J. Biochem. 1965, 43, 1745-1753.

Maxwell, M. E.: Production of protease by cultivation of Aspergillus oryzae on wheat bran. Aust. J. appl. Sci. 1950, 1, 348-362.

Narayanan, A.S. \& E. R. B. Shanmugasundaram: Studies on proteinase of Fusarium vasinfectum ATK. Enzymologia 1966, 30, 279-289.

Roper, K. B. \& D. I. Fennell: In The Genus Aspergillus. The Williams \& Wilkins Company, Baltimore 1965, pp. 291, 335, 391-393, $395,415,541$.

Rutqvist, L.: Studies on Aspergillus fumigatus; toxin production by different strains and serological comparison of the strains. Acta vet. scand. $1965,6,224-233$.

Rutqvist, L.: Studies on Aspergillus fumigatus; stability of haemolysin and toxin in crude filtrate. Acta vet. scand. 1968, 9, 350-363.

Rutqvist, L. \& P. A. Persson: Studies on Aspergillus fumigatus, experimental mycotoxicosis in mice, chicks and pigs with the appearance, in pigs, of perirenal edema. Acta vet. scand. 196?, 7 , 21-34. 
Sandvik, O.: Studies on casein precipitating enzymes of aerobic and facultatively anaerobic bacteria. Thesis, Oslo 1962.

Sandvik, O.: Identification of moulds by serologic differentiation of their proteolytic enzymes. Acta path. microbiol. scand. 1967, 71, 333-338.

Schäffer: Fermente in Schimmelpilzen. (Ferments in moulds). Thesis, Erlangen 1900, Cit. v. Pechman, E.: Biochem. Z. 1951, 321, $549-559$.

Sörensen, S. P. L.: Enzymstudien. (Studies of enzymes). Biochem. Z. 1908, 7, 45-101.

Tran Van Ky, P., J. Uriel \& F. Rose: Caractérisation de types d'activités enzymatiques dans des extraits antigéniques d'Aspergillus fumigatus après électrophorèse et immunoélectrophorèse an agarose. (Characterization of enzymatic activity types in antigenic extracts of Aspergillus fumigatus by means of electrophoresis and agarose-immunoelectrophoresis). Ann. Inst. Pasteur 1966, 111, 161-170.

\section{SUMMARY}

In filtrates of mycelial material from Aspergillus fumigatus, cultured in proteose-peptone-yeast extract broth for 3 days at $37^{\circ} \mathrm{C}$, the presence of proteolytic enzyme could be demonstrated in addition to haemolysin and toxin. A study was made of the casein precipitating ability of the enzyme, as well as of its casein and gelatin hydrolyzing effect.

On precipitation of filtrate with ethanol, acetone or ammonium sulphate, the highest casein precipitating activity per $\mathrm{mg} \mathrm{N}$ was demonstrated in the precipitate of filtrates precipitated with 3 parts ethanol. This precipitate contained no measurable haemolytic and only inappreciable toxic activities. The haemolytic and toxic activities per $\mathrm{mg} \mathrm{N}$ were greatest in precipitates of ammonium sulphate-treated filtrates.

\section{ZUSAMMENFASSUNG}

Studien über Aspergillus fumigatus; Kasein-präzipitierende und proteolytischen Eigenschaften der Filtrate von Myzelienkulturen.

In Myzelienfiltraten von Aspergillus fumigatus-Kulturen konnte neben Toxin und Hämolysin auch ein proteolytisches Enzym nachgewiesen werden. Das Kasein-präzipitierende Vermögen des Enzymes sowie seine Kasein- und Gelatine-hydrolysierende Wirkung wurden untersucht.

Nach Präzipitation der Filtrate mit Äthylalkohol, Azeton oder Ammoniumsulphat erwies sich, dass die Kasein-präzipitierende Aktivität per mg $\mathbf{N}$ höchsten in mit Äthylalkohol hergestellten Fällungen war. Keine messbare hämolytische und nur geringe toxische Aktivität war in diesen Präzipitaten nachweisbar. Das proteolytische Enzym dürfte demnach eine von den bereits früher beschriebenen Kompo- 
nenten, dem Hämolysin und dem Toxin, ein weiterer, selbständiger Bestandteil der Filtrate sein. Die hämolytische und toxische Wirkung war per mg $\mathbf{N}$ am stärksten in den mit Ammoniumsulphat hergestellten Fällungen.

\section{SAMMANFATTNING}

Studier av Aspergillus fumigatus; kaseinprecipiterande och proteolytisk verkan hos myceliefiltrat.

I filtrat från myceliematerial från Aspergillus fumigatus, som kultiverats i proteos-pepton-jästextraktbuljong under 3 dagar vid $37^{\circ} \mathrm{C}$ påvisades förutom hämolysin och toxin även förekomst av proteolytiskt enzym. Enzymets kaseinprecipiterande förmåga samt dess kasein- och gelatinhydrolyserande verkan har undersökts.

Vid precipitation av filtrat med etanol, aceton eller ammoniumsulfat påvisades den högsta kaseinprecipiterande aktiviteten per mg $\mathrm{N}$ i precipitat från filtrat som fällts med 3 delar etanol. I detta precipitat påvisades samtidigt ingen mätbar hämolytisk och endast ringa toxisk aktivitet. De hämolytiska och toxiska aktiviteterna var per mg $\mathrm{N}$ störst i precipitat från ammoniumsulfatbehandlat filtrat.

(Received July 8, 1968). 